\title{
A Spatial and Temporal Study of the Green and Blue Water Flow Distribution in Typical Ecosystems and its Ecosystem Services Function in an Arid Basin
}

\author{
Chuanfu Zang ${ }^{1}$ and Ganquan Mao ${ }^{2,3, *(1)}$ \\ School of Geography, South China Normal University, Guangzhou 510631, China; chuanfuzang@163.com \\ 2 School of Environmental Science and Engineering, Southern University of Science and Technology, \\ Shenzhen 518055, China \\ 3 State Key Laboratory of Water Resources and Hydropower Engineering Science, Wuhan University, \\ Wuhan 430072, China \\ * Correspondence: maogq@sustc.edu.cn; Tel.: +86-189-2645-3724
}

Received: 4 December 2018; Accepted: 3 January 2019; Published: 8 January 2019

\begin{abstract}
Research on relationship between green and blue water flow and ecosystem service functions has great significance for improving water resources management and for ecological protection. In this study, the distribution patterns and service functions of green and blue water flow in different ecosystems were analysed by Soil and Water Assessment Tool (SWAT) model simulation and Correlational Analysis. In the entire basin, the amount of green and blue water flow in the grassland was greater than that in the cropland, and that in the cropland was larger than that in the forest. The corn yield per hectare of cropland was highest in the Heihe River Basin, followed by wheat, and the lowest yield was the oil yield from 2000 to 2010. The mutton yield in the grassland ecosystem was greater than the beef yield from 2000 to 2010, which shows that the beef production would consume more water flow. Results show an obvious positive correlation between green or blue water flow and wheat and corn yields. Beef and mutton had a significant correlation with blue water flow, whereas mutton had a stronger correlation with green water flow.
\end{abstract}

Keywords: green water flow; blue water flow; ecosystem services; Heihe River Basin

\section{Introduction}

Freshwater is essential for life because all organisms on the planet require fresh water resources to ensure their survival [1-3]. According to the definition of Falkenmark [4], water resources can be divided into green and blue water. Blue water is mainly water stored in rivers, lakes and shallow groundwater. At present, the water directly used by human beings in daily life is basically blue water. Green water refers to the water that originates from precipitation, is stored in unsaturated soil and is absorbed and undergoes transpiration by plants [4]. Green water plays an irreplaceable role in global ecosystems and food production. Liu et al. [5] estimated that $80 \%$ of global food production depends on green water, and the supply of water in grassland and forest ecosystems is mainly dependent on green water. In recent years, green/blue water research has triggered the rethinking of water resources concepts and evaluations by the scientific community, gradually affecting human thinking about water resources management, and it has become a hot research in the field of hydrology and water resources [6,7]. First, green water is an important source of water for terrestrial ecosystems because it plays a key role in maintaining the coordination of terrestrial ecosystems and ecosystem health. Second, green water is the only resource that supports rainfed agriculture. In total, $83 \%$ of the cultivated land provides food security for $70 \%$ of the world's population [8]. Finally, green water 
plays an irreplaceable role in maintaining the function and service functions of the Earth's terrestrial ecosystem [6].

From the point of view of material circulation, the concept of green and blue water flow has been introduced in many studies [8-10], and the green water flow is the actual evapotranspiration. From the perspective of the global water cycle, $65 \%$ of the total precipitation on the global scale is returned to the atmosphere through evapotranspiration of forests, grasslands, farmlands and so on, becoming green water flow [11]. The surface runoff, the mid-soil flow, and the underground runoff are combined into the blue water flow [12-14]. In this article, we focus on green and blue water flow. The concept of green and blue water flow closely relates the water cycle to the ecological process, which reflects the interaction between the ecosystem and hydrological processes $[3,15]$. The concept of green and blue water flow not only broadens the scientific connotation of water resources research but also has provided new theories and ideas for water resources research and management $[6,7]$.

Currently, the evaluation of green and blue water flow currents is mainly concentrated on the global or basin scale with a focus on the evaluation of green and blue water flow and their spatial and temporal distribution $[5,9,16,17]$. However, there is little research on green and blue water flow on the ecosystem scale, especially the combination of green and blue water flow and ecosystem service functions. Ecosystem service function is one of the main topics of the United Nations Millennium Ecosystem Assessment [18-20]. It plays an important role in global ecosystem management and sustainable development research and is the basis for understanding the interaction between ecosystems and humans [21-23]. Although freshwater demand for the production of these ecosystem services is often invisible, maintaining these functions consumes large amounts of green water flow [24]. To date, researchers have performed many studies evaluating the supply and regulation functions of typical ecosystem services $[25,26]$, and many models and methods are used to study the function of ecosystem services [25-27], such as the In-VEST (Integrated Valuation of Ecosystem Services and Tradeoffs) model is a classic model used to evaluate ecological services $[27,28]$. However, there are few studies that combine the support function of the ecosystem services, especially the comprehensive evaluation of water resources consumption and ecosystem services as a whole $[21,25,26]$. In short, the interrelationship between the hydrology, ecology and human activities is not clear. There is still insufficient scientific basis for applying regional ecosystem and water resources management.

The Heihe River Basin is location in arid regions of China, and researchers have paid much attention to the regional water cycle and ecosystem service functions based on blue water flow [24]; However, the green water flow, the green water flow, which is important to river basin ecosystem service functions and to human beings, and the connections between water resources and ecosystem services are still need to strengthen understood. The main objectives of this study were to determine how to quantitatively assess the resources of green and blue water flow in typical ecosystems (cropland, forest, and grassland) and to determine how to analyse the relationship between green and blue water flow and ecosystem services in the typical ecosystems of the Heihe River Basin. For this study, we selected the Heihe River Basin, which is a typical inland river in an arid area as the research object. This study is a follow-up of our previous research. We calibrated and validated the Soil and Water Assessment Tool (SWAT) model for the simulation of the flows of green and blue water at the whole-basin level by comparing simulated and measured discharge, as shown in Zang et al [9]. The calibration and validation performed were very satisfactory. The study consists of the following parts: (1) an analysis of the spatial and temporal distribution of green and blue water flow in typical ecosystems; (2) consideration of the consumption of green and blue water flow in typical ecosystems; and (3) a comprehensive evaluation of green and blue water flow and ecosystem services as a whole. Our research will provide new ideas for water resources and ecosystem services research and provide a theoretical basis for ecosystem and water resources assessment of inland river basins. 


\section{Materials and Methods}

The research framework of the proposed study is shown in Figure 1. To assess green and blue water flow for ecosystem services, the typical ecosystems, including cropland, forest and grassland ecosystems, were mainly divided using land use data. First, we assessed how much green and blue water flow in croplands, forests, and grasslands. Second, we analysed the ecosystem services in croplands, forests, and grasslands. We also determined the green and blue water flow consumption to support ecosystem services. Finally, the relationship between green and blue water flow and ecosystem services in the typical ecosystems was analysed.

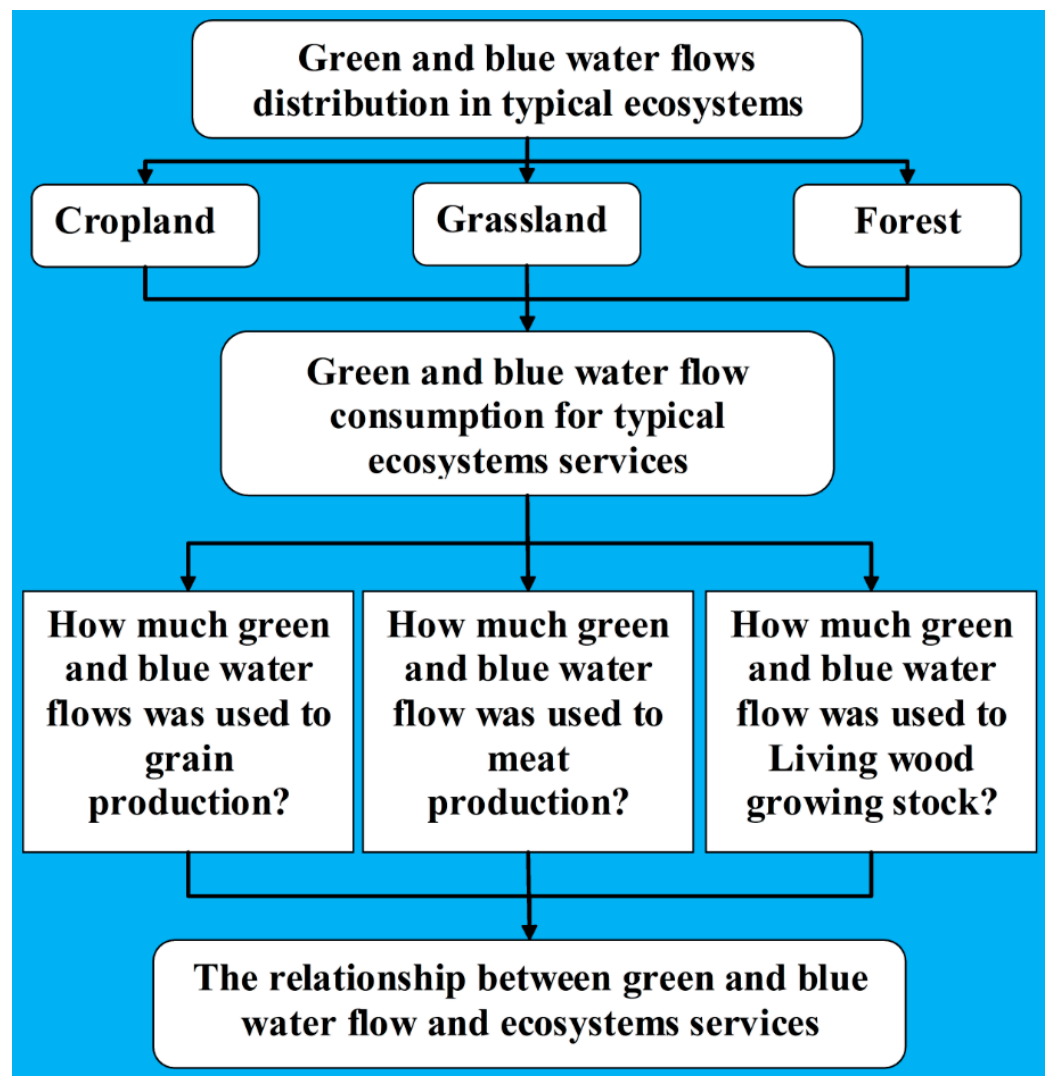

Figure 1. The research framework of this article.

\subsection{Study Area}

The Heihe River is the second largest inland river in China, and the basin area is 0.24 million $\mathrm{km}^{2}$ with a length of $821 \mathrm{~km}$ for the major channel (Figure 2). The latitude and longitude are between $98^{\circ}-101^{\circ} 30^{\prime} \mathrm{E}$ and $38^{\circ}-42^{\circ} \mathrm{N}$ (Figure 2), respectively. The Heihe River Basin is located in the central part of Eurasia away from the ocean and is surrounded by mountains. The climate is dry, precipitation is rare and concentrated, the wind is strong, sunshine is sufficient, and the solar radiation is strong. The climate of the Heihe River Basin has obvious north-south differences [6,24]. In the Qilian Mountains in the south, the precipitation decreases from east to west, and the height of the snow line gradually increases from east to west. The precipitation in the Heihe River Basin of the Central Corridor is $250 \mathrm{~mm}$, and the average potential evapotranspiration is $2000 \mathrm{~mm} \mathrm{[24].} \mathrm{The} \mathrm{average} \mathrm{annual}$ temperature of the upper reaches is $1.5-2.0{ }^{\circ} \mathrm{C}$, the annual precipitation is above $300 \mathrm{~mm}$, the relative humidity is approximately $60 \%$, and the average potential evapotranspiration is approximately $700 \mathrm{~mm}$. The average annual temperature in the middle reaches is $2.8-7.6^{\circ} \mathrm{C}$, the average annual precipitation is between 200 and $300 \mathrm{~mm}$, and the average annual potential evapotranspiration is more than $1200 \mathrm{~mm}$. The average annual precipitation is less than $50 \mathrm{~mm}$ in the down reaches, the average annual 
potential evapotranspiration is more than $3500 \mathrm{~mm}$, and the average annual temperature is $8.04{ }^{\circ} \mathrm{C}$ [24]. The main land cover types of the basin include forest mainly in the upstream, cropland mainly in the midstream and grassland and desert mainly in the downstream; these three land covers together account for $80 \%$ of the total basin area (Figure 2).

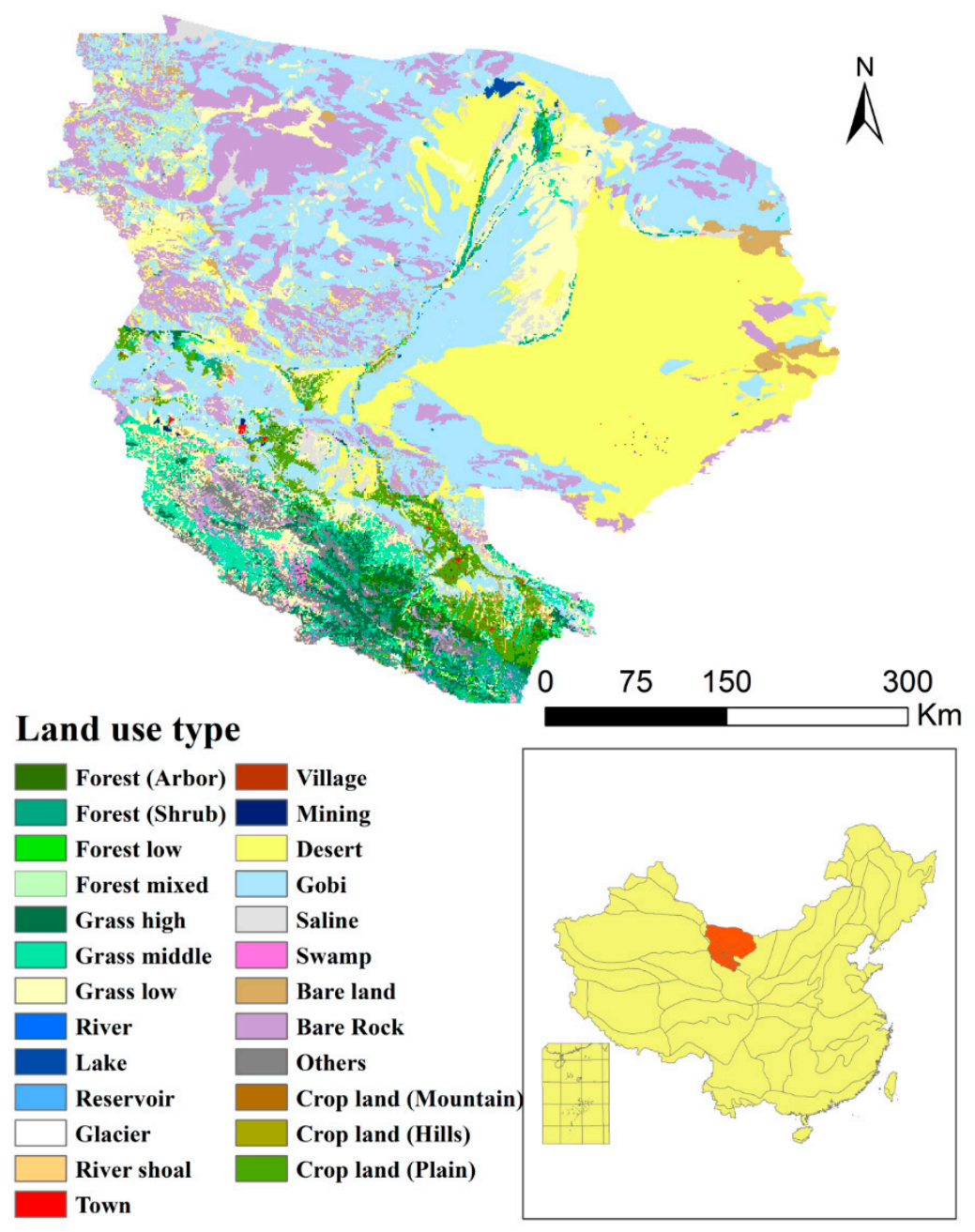

Figure 2. Location and land use types in 2005 of the Heihe River Basin.

\subsection{Data Treatment of the Green and Blue Water Flow}

The green water flow is actually evapotranspiration, whereas the sum of surface runoff, lateral flows, and groundwater recharge is treated as blue water flow [13]. The data on green and blue water flow was obtained from simulations of the Soil and Water Assessment Tool (SWAT) [29]. In our previous research, we divide the discharge data into two periods: a calibration (1979-1987) and a validation period (1990-2004). Based on the built-in sensitivity analysis tool in SWAT, we have identified the 14 most sensitive parameters [9]. We simulate the green and blue water flow at the whole basin level using data from 1980 to 2010 [9,14]. The calibration and validation performed with SWAT at the two hydrological stations was satisfactory, as indicated by high values of $E_{n s}$ and $R^{2}[9,14]$. In previous research, the $E_{n s}$ and $R^{2}$ values were more than 0.85 in the upstream and more than 0.65 in the midstream, which showed that we had good calibration and validation results for the present study. In SWAT, the Heihe River Basin area is divided into multiple sub-basins and hydrological response units (HRUs) by overlaying elevation, land cover, soil, and slope classes, the entire river basin was divided into 311 HRUs and 32 sub-basins on the basis of land use, soil, and slope classes. Further information on the model simulation, calibration, and validation can be found in Zang et al. $[9,14]$. 
The daily precipitation and temperature data were offered by the Heihe data research group [30]. The 1-km land use data for 2005 were obtained from the Institute of Resources and Environment Data Cloud Platform, Chinese Academy of Sciences (CAS) [31]. The soil data were obtained from the Harmonized World Soil Database (HWSD) with a spatial resolution of approximately $1 \mathrm{~km}$ [32]. We used data from 19 weather stations for our simulation. The SWAT model was used to first calculate the rainfall interception by plant canopy and then the maximum plant transpiration and soil evaporation using an approach similar to Ritchie [29]. The actual plant transpiration and soil evaporation were then calculated based on the soil moisture balance following Neitsch et al. [33]. Potential evapotranspiration was estimated by the Hargreaves method [34], and surface runoff was calculated using the Soil Conservation Service (SCS) curve number $(\mathrm{CN})$ method [33]. We used the SUFI-2 (Sequential Uncertainty Fitting algorithm version 2) approach from the SWAT-CUP interface [35] to optimize the parameters. $E_{n s}$ and $R^{2}$ values were used to evaluate the goodness of the calibration and validation process.

In the present study, we used the calibration results and parameters derived in the previous study but expanded the period to 1971-2010 and the research content to the ecosystem level. We integrated different types of forest lands (forest (arbor), forest (shrub), forest low and forest mixed) as forest ecosystems and different types of croplands (cropland in the mountains, cropland in the hills, cropland in the plain) into farmland ecosystems, and grasslands of different densities (grass high, grass middle and grass low) were classified as grassland ecosystems. The land use influences the surface runoff generation rate and evapotranspiration. In the SWAT model, we have different parameters, e.g., curve numbers, for different land cover types (e.g., grassland, crop and forest) [33].

\subsection{Ecosystem Services Data Sources and Treatment for Green and Blue Water Flow}

We calculated the green and blue water flow from 1971 to 2010 according to the different land use types on the sub-basin level. Then, we classified the green and blue water flow in the ecosystem by land use type for 2005. In the present study, we used the calibration parameters derived in the previous study $[9,14]$, but expanded the simulation period to 1970-2010. The first years were used as a warm-up period in the model to mitigate the effect of unknown initial conditions, and these years were then excluded from the analysis.

The ecosystem services data for the cropland and grassland were obtained from the China Economic and Social Development Statistics Database [36]. Based on the completeness and availability of the statistics, we collected data on food, cereal, beef and mutton production data for the period of 2000-2010 for the following reasons. First, most of the statistical data for the study area began after the 1990s, and more complete statistical data began in the 2000s. Second, we used the land use data for 2005, which is at the middle of the period of 2000-2010. Since pork and chicken are mostly raised in captivity and because food for pigs and chickens may come from cropland or from grassland, it is difficult to classify to which ecosystem these belong; thus, this study did not include pork or chicken. We selected the living wood growing stock as the ecosystem services for the forest ecosystem. The living wood growing stock refers to the total amount of trees accumulated on the land within a certain time period, including forest accumulation, sparse forest accumulation, and scattered wood accumulation [37]. The reasons we chose living wood growing stock are as follows. First, it is the most important indicator for calculating forest biomass and carbon storage. Second, it can reflect well indicators of all forest land types in the Heihe River Basin, including sparse forest land and mixed forest land. The living wood growing stock data are from the Northwest Forestry Investigation and Planning Institute of the State Forestry Bureau [38]. First, we collected the data according to the county-level administrative district and then converted it to the basin scale. Datasets that covered the entire administrative area of the basin were used directly. If the data covered only part of the administrative area in the basin, we first converted the data to a value per unit area and then multiplied that by the area of the basin. 
As food production is susceptible to planting structures in different years, food production was converted into food production per unit area $(\mathrm{kg} / \mathrm{Ha})$. Additionally, the green and blue water flow for the corresponding year were also converted into a unit area $\left(\mathrm{m}^{3} / \mathrm{Ha}\right)$. To analyse the accuracy of the results, the production of beef and mutton and the living wood growing stock were also converted to the value per unit area. Correlation analysis methods were applied to investigate the relationship between green and blue water flow and the corresponding ecosystem services [39]. Then, linear regression analysis and the Pearson test method were used to examine if the result was significant in the given confidence interval or not [40].

\section{Results}

\subsection{Spatial and Temporal Distributions of Green and Blue Water Flow in the Typical Ecosystem}

According to the graph in Figure 3, the green and blue water flow per unit area in the forest ecosystem was greater than that in the farmland ecosystem; that in the cropland ecosystem was larger than that in the grassland ecosystem. From 1971 to 2010, the average annual green and blue water flow in forest, cropland, and grassland ecosystems were $397.3 \mathrm{~mm}, 286.6 \mathrm{~mm}$, and $207.7 \mathrm{~mm}$, respectively (Figure 3a).

The green water flow per unit area in the forest ecosystem was greater than that in the farmland; that in the farmland ecosystem was larger than that in the grassland ecosystem from 1971 to 2010 (Figure 3b). The average annual value for green water flow per unit in the forest, cropland, and grassland ecosystems were $306.4 \mathrm{~mm}, 260.9 \mathrm{~mm}$, and $173.2 \mathrm{~mm}$, respectively (Figure 3b). In contrast to the green water flow per unit area, the blue water flow per unit area in the forest ecosystem was greater than that in the grassland ecosystem, and the value for the grassland ecosystem was larger than that for the cropland ecosystem (Figure 3c). From 1971 to 2010, the average annual blue water flow per unit area in the forest ecosystem was $90.9 \mathrm{~mm}$, that in the grassland was $34.5 \mathrm{~mm}$, and that in the cropland was $25.7 \mathrm{~mm}$ (Figure 3c).

After multiplying the area with the values for green and blue water flow per unit area, we obtained the green and blue water flow in volume. In contrast to the distribution characteristics of the green and blue water flow per unit area, the green and blue water flow in the grassland ecosystem was greater than that in the cropland ecosystem, and that in the cropland was more than that in the forest ecosystem (Figure 4a). The average annual green and blue water flow were 3.77 billion $\mathrm{m}^{3}$ for the grassland, 3.14 billion $\mathrm{m}^{3}$ for the cropland and 2.47 billion $\mathrm{m}^{3}$ for the forest from 1971 to 2010, (Figure 4a).

According to Figure $4 b$, the green water flow in terms of volume in the grassland ecosystem was greater than in the cropland, and the forest ecosystem had the least. The average annual quantities of green water flow in terms of volume were 3.07 billion $\mathrm{m}^{3}$ in the grassland, 2.94 billion $\mathrm{m}^{3}$ in the cropland, and 1.91 billon $\mathrm{m}^{3}$ in the forest from 1971 to 2010 (Figure 4b). The blue water flow in terms of volume in the grassland was greater than that in the forest ecosystem, and the cropland had the least (Figure 4c). From 1971 to 2010, the average annual values for blue water flow in terms of volume were 0.71 billion $\mathrm{m}^{3}$ in the grassland, 0.57 billion $\mathrm{m}^{3}$ in the forest, and 0.21 billion $\mathrm{m}^{3}$ in the cropland (Figure 4c). 


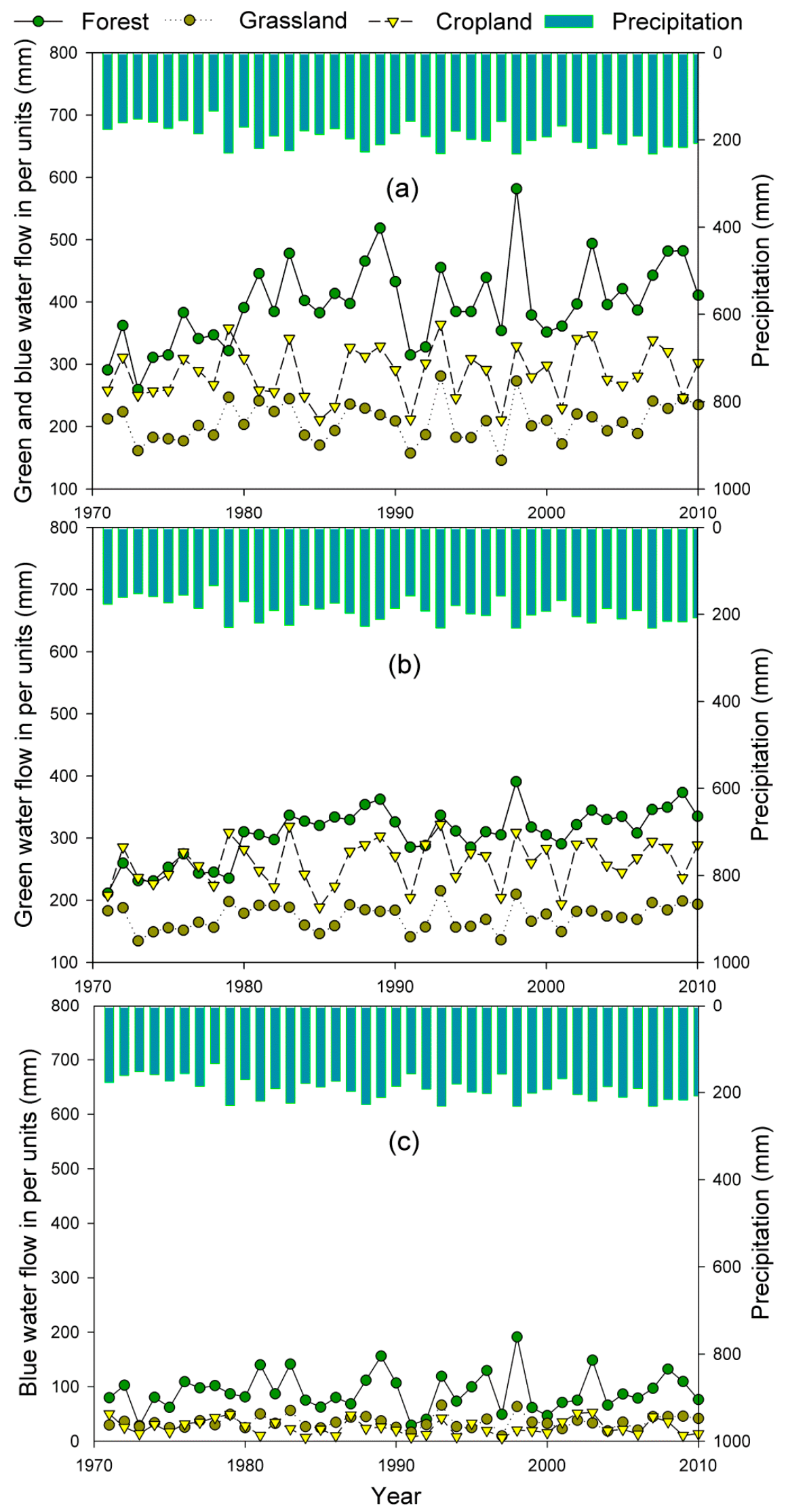

Figure 3. Green and blue water flow in terms of per units of the typical ecosystem. (a) is green and blue water flow in per units, (b) is green water flow in per units, (c) is blue water flow in per units. 

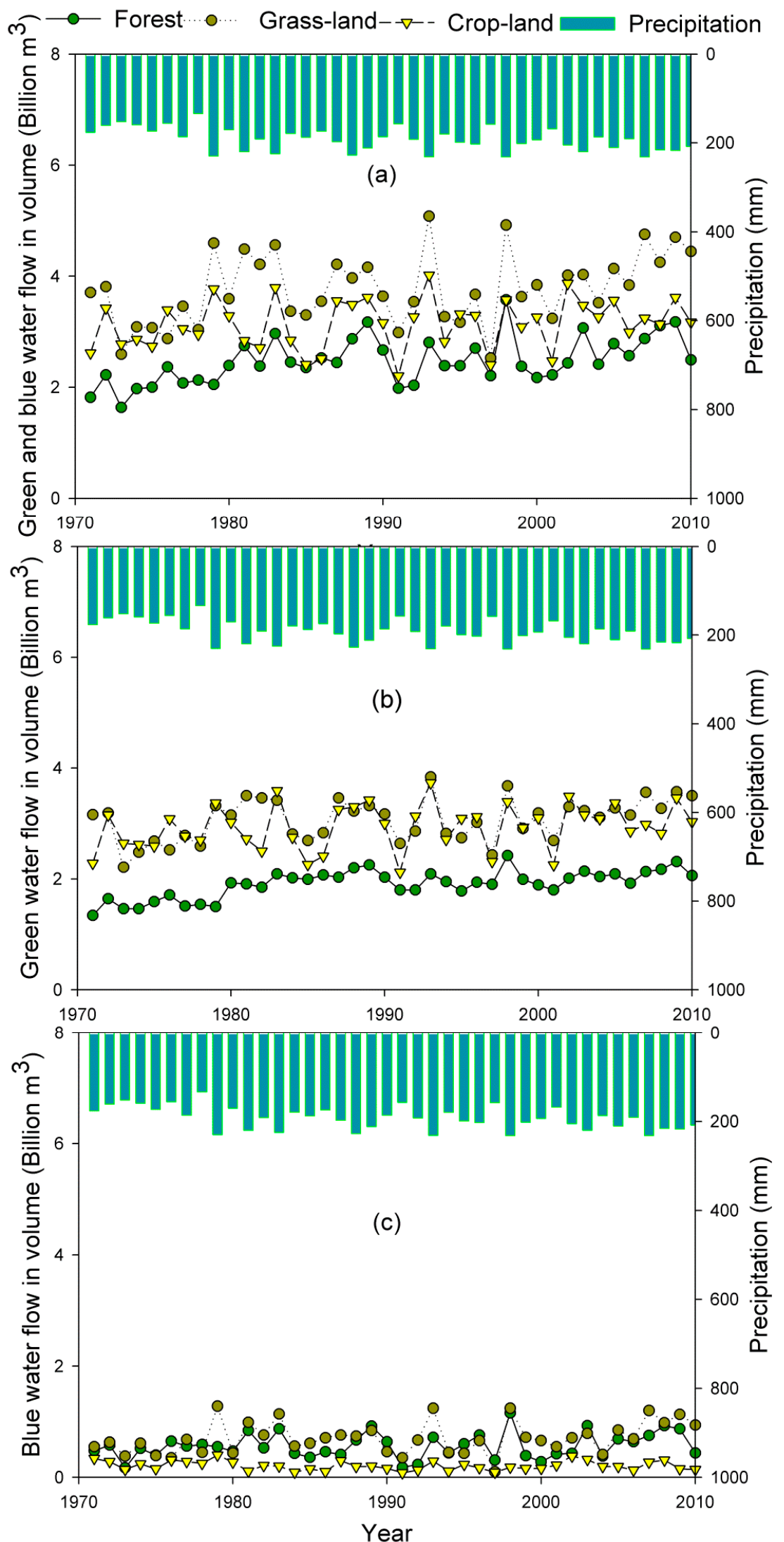

Figure 4. Green and blue water flow in terms of volume of the typical ecosystem. (a) is green and blue water flow in volume, (b) is green water flow in volume, (c) is blue water flow in volume. 


\subsection{Ecosystem Services of Typical Ecosystems in the Heihe River Basin}

As shown in Figure 5, we found that the corn yield per hectare of cropland was the highest in the Heihe River Basin, followed by wheat, and the lowest yield was the oil yield from 2000 to 2010. Because grain yield includes corn and wheat production, it also includes other types of food crops, e.g., sorghum, millet and others. Therefore, it represents the average cropland food production in the Heihe River Basin. The grain yield in the Heihe River Basin was $7503 \mathrm{~kg} / \mathrm{Ha}$, the corn yield was $8200.4 \mathrm{~kg} / \mathrm{Ha}$, the wheat yield was $6423.7 \mathrm{~kg} / \mathrm{Ha}$, and the oil yield was $2839.8 \mathrm{~kg} / \mathrm{Ha}$ from 2000 to 2010 , respectively (Figure 5). The mutton yield in the grassland ecosystem was greater than the beef yield from 2000 to 2010 (Figure 6). The quantity of mutton in the grassland was $11 \mathrm{~kg} / \mathrm{Ha}$, and the quantity of beef was $3.8 \mathrm{~kg} / \mathrm{Ha}$ from 2000 to 2010 (Figure 6). According to Figure 7, living wood growing stock is a relatively stable indicator, unless there is a big disaster, and there will be no significant variability. As observed, the living wood growing stock had no significant variability from 2000 to 2010 with the average annual value at $31.8 \mathrm{~m}^{3} / \mathrm{Ha}$ (Figure 7 ).

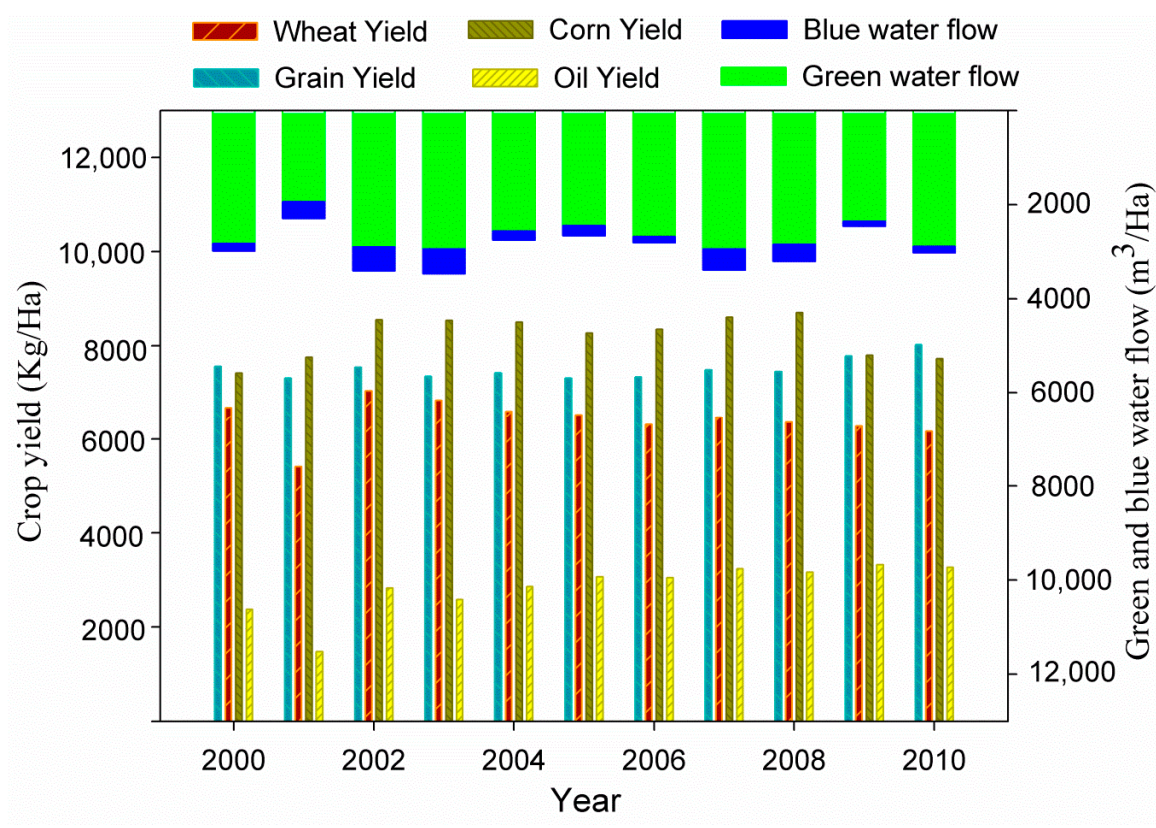

Figure 5. Ecosystem services of green and blue water flow for croplands.

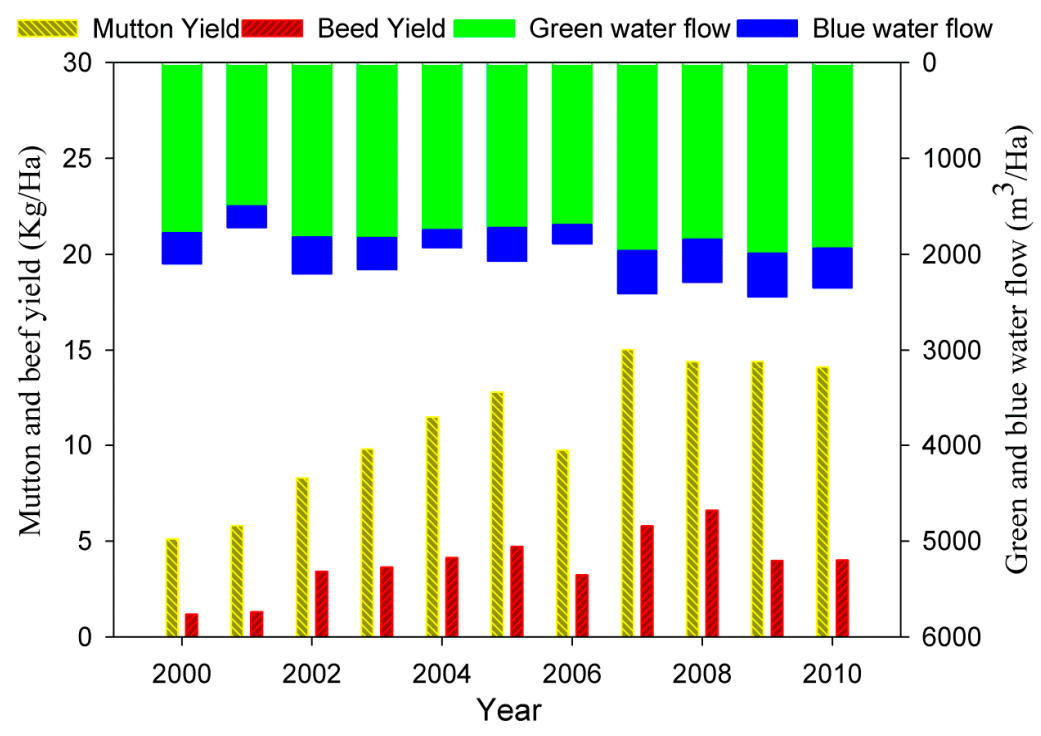

Figure 6. Ecosystem services of green and blue water flow for grasslands. 


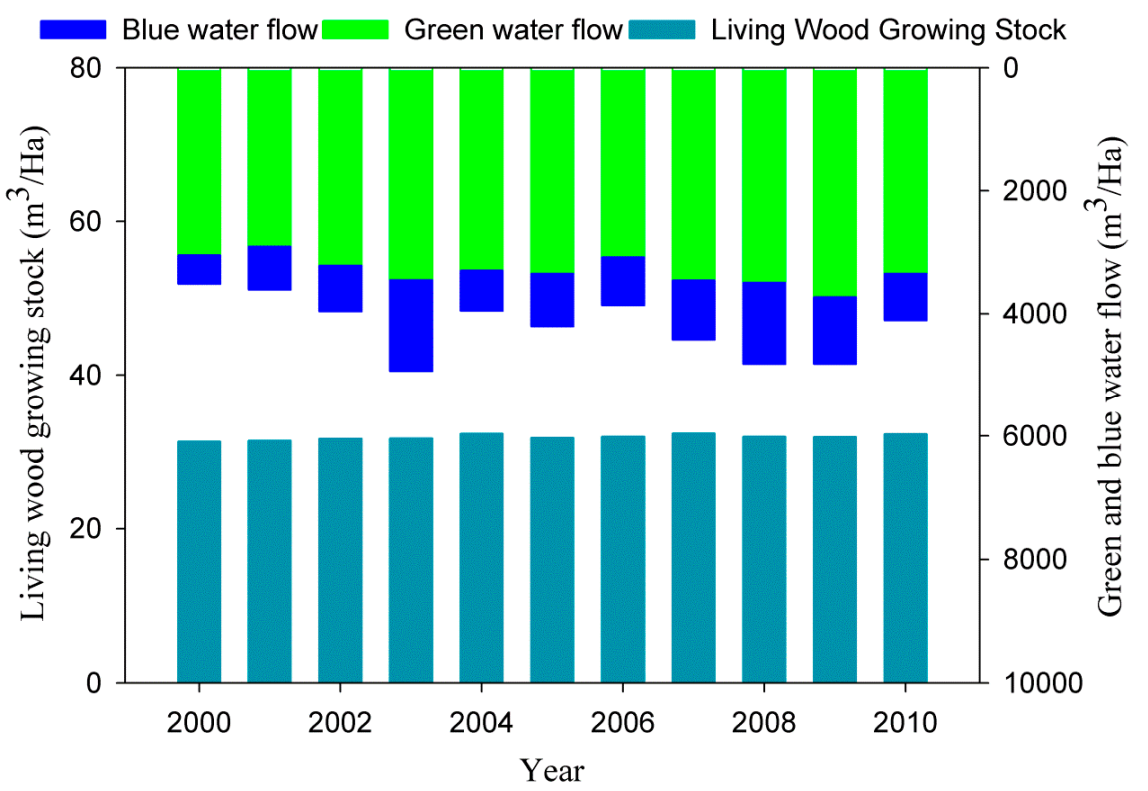

Figure 7. Ecosystem services of green and blue water flow for forests.

\subsection{Relationship of the Green and Blue Water Flow in Typical Ecosystems and its Ecosystem Service Functions}

According to Figure 5, there is an obvious positive correlation between green or blue water flow and the wheat and corn yields. These consumed $2668 \mathrm{~m}^{3}$ of the green water flow and $284 \mathrm{~m}^{3}$ of the blue water flow per hectare in the cropland ecosystem, which produced $8200 \mathrm{~kg}$ of corn or $6424 \mathrm{~kg}$ of wheat per hectare from 2000 to 2010 (Figure 5). According to Tables 1 and 2, the corn yield is significantly correlated at the 0.05 level with the blue water flow, and wheat is significantly correlated at the 0.01 level with the green water flow. In the grassland ecosystem, there was $1800 \mathrm{~m}^{3}$ of green water flow and $342 \mathrm{~m}^{3}$ of blue water flow per hectare consumed, which produced $11 \mathrm{~kg}$ of mutton or $3.8 \mathrm{~kg}$ of beef per hectare from 2000 to 2010 (Figure 6). Mutton production is significantly correlated at the 0.05 level with the blue water flow and is a significantly correlated at the 0.01 level with the green water flow. The beef production is significantly correlated at the 0.05 level with the blue water flow (Table 1; Table 2). The living wood growing stock is a significantly correlated at the 0.05 level with the green water flow (Table 1; Table 2), there was a consumption of $3307 \mathrm{~m}^{3}$ of green water flow and $896 \mathrm{~m}^{3}$ of blue water flow per hectare, which generated $31.8 \mathrm{~m}^{3}$ living wood growing stock per hectare from 2000 to 2010 (Figure 7). According to Table 2, when $x=0$, the wheat yield is 3787 tons. This indicates that wheat production will increase as green water flow increases, corn and beef has the same trend with blue water flow (Table 1; Table 2). According to Table 2, when $\mathrm{x}$ is 0 , the mutton yield is $-20.7 \mathrm{Kg}$. This indicates that lamb production will occur when the green water flow per hectare of grassland exceeds $1177 \mathrm{~m} 3$. When $\mathrm{x}$ is 0, the Living Wood Growing Stock yield is $29.6 \mathrm{~m}^{3}$, this indicates that Living Wood Growing Stock production will increase as green water flow increases (Table 2).

Table 1. Pearson correlation test results.

\begin{tabular}{ccc}
\hline Variable & R (Blue Water) & R (Green Water) \\
\hline Grain & -0.382 & 0.263 \\
Wheat & 0.291 & $0.738^{* *}$ \\
Corn & $0.614^{*}$ & 0.391 \\
Oil Plants & -0.257 & 0.529 \\
Living Wood Growing Stock & 0.376 & $0.654^{*}$ \\
Beef & $0.615^{*}$ & 0.586 \\
Mutton & $0.701^{*}$ & $0.743^{* *}$ \\
\hline
\end{tabular}

Note: $\mathrm{R}$ is the correlation coefficient; ${ }^{*}$ significantly correlated at the 0.05 level; ${ }^{* *}$ significantly correlated at the 0.01 level. 
Table 2. Linear regression equations of green and blue water flow for different ecosystem functions.

\begin{tabular}{ccc}
\hline Variable & Blue Water Flow & Green Water Flow \\
\hline Grain Yield & $\mathrm{y}=-0.525 \mathrm{x}+7652.3$ & $\mathrm{y}=0.1788 \mathrm{x}+7026$ \\
Wheat Yield & $\mathrm{y}=0.7808 \mathrm{x}+6201.9$ & $\mathrm{y}=0.9881 \mathrm{x}+3787.3$ \\
Corn Yield & $\mathrm{y}=1.6521 \mathrm{x}+7731.1$ & $\mathrm{y}=0.5485 \mathrm{x}+6736.8$ \\
Oil Plants Yield & $\mathrm{y}=-0.8381 \mathrm{x}+3077.9$ & $\mathrm{y}=0.9071 \mathrm{x}+419.64$ \\
Beef Yield & $\mathrm{y}=0.0089 \mathrm{x}+0.7554$ & $\mathrm{y}=0.0065 \mathrm{x}-7.8804$ \\
Mutton Yield & $\mathrm{y}=0.0212 \mathrm{x}+3.7285$ & $\mathrm{y}=0.0176 \mathrm{x}-20.707$ \\
Living Wood Growing Stock & $\mathrm{y}=0.0003 \mathrm{x}+31.494$ & $\mathrm{y}=0.0007 \mathrm{x}+29.602$ \\
\hline
\end{tabular}

\section{Discussion}

In this paper, we first applied the SWAT model to simulate the green and blue water flow in an arid river basin in China. Then, the temporal and spatial dynamic distribution of green and blue water flow for typical ecosystems (forest, cropland, and grassland) were analysed. A detailed investigation of the relationship between green and blue water flow and ecosystem service functions in typical ecosystems was conducted. In this study, the blue water flow and green water flow per unit area of the forest were the highest. In the grassland and farmland, the green water flow per unit area of farmland was higher than that of the grassland, whereas the blue water flow for the grassland was higher than that of the farmland from 1971 to 2010 in the Heihe River Basin. First, this is related to the natural distribution of the typical ecosystems in the Heihe River Basin. The forest ecosystems are mainly distributed in the upper reaches, the farmland is mainly distributed in the middle reaches, and grasslands are mainly distributed in the upstream and middle reaches (Figure 1). Additionally, only a part of the low-density grasses are distributed downstream (Figure 1). Second, this is due to climatic factors of the different reaches of the Heihe River Basin [24]. Therefore, such precipitation and evapotranspiration conditions from the up to down reaches determine the distribution characteristics of the green and blue water flow in the area [41,42]. Finally, and most importantly, these conditions are determined by the structural characteristics of the typical ecosystems themselves. In the upper reaches of the Heihe River, the forest is dominated by coniferous forests; forest canopy density and water consumption are relatively low compared with broad-leaf species. When precipitation through the forest forms a canopy interception, interflow and surface runoff, thus forming a blue water flow. Furthermore, farmland has a larger leaf area index and vegetation interception than grassland. The tall canopy then forms a shade, reduce surface runoff and reducing blue water flow $[43,44]$. Therefore, this produce more green water flow. When the precipitation passing through the grassland quickly forms surface runoff and interflow, its causes more blue water flow [45]. The interception for the farmland is relatively high due to the planting density of the farmland, which can influence the hydrological processes of green and blue water flow [46].

This study is limited by several shortcomings. First, due to the characteristics of the SWAT model itself and the limited resolution of the land use data, the accuracy of the ecosystem division was affected. For example, forests can be divided into trees, shrubs, and sparse forests, or they can be divided into forest ages; however, these divisions are implemented in large-scale models. The same is true for farmlands and grasslands. This may impact the simulation results of the model. Because the ecosystem service functions use statistical data, the land use data used by the ecosystem is divided, which results in some deviation. Similar problems have arisen when researchers have used the in-VEST model [28]. Researchers have been troubled by the question of how to solve the problem of large-scale simulation and small-scale verification. Therefore, the study of ecosystem service functions on a large scale and the precise division of ecosystems need to be further improved $[47,48]$. Second, in this study, we did not adequately consider the effects of irrigation water use or land use change. Clearly, human activities, especially irrigation and land use change, have already significantly influenced the water cycle in the Heihe River Basin. However, the extent of hydrological responses to human intervention has not been quantitatively assessed. The current study provides the first step for quantifying the relationship between green and blue water flow and service functions in typical ecosystems. However, 
the impact of human activities on the temporal and spatial changes of green and blue water flow in typical ecosystems and the mechanism of human functions on ecosystem services need to be further explored. Lastly but most important, in our study, we just choose the representative ecosystem in our research domain which are the forest, cropland and grassland. In this study, we investigated three ecosystem services that are closely related to the selected ecosystems, i.e. crop yield, beef, and mutton. The representative ecosystem services are important for a case study, but other ecosystem services are also very important. Therefore, in further study, it is also interesting to analyse other ecosystem services thus provide different viewpoints for the different ecosystem services.

As shown in this study, less green and blue water flow consumption per hectare of farmland can produce more grain. The yield of beef and mutton per hectare of grassland in the Heihe River Basin was lower, but it consumed more blue water flow than the farmland. This is mainly because the basin is mostly middle and low-density grassland. Among the three ecosystems, the forest consumed the highest amount of green and blue water flow per hectare, indicating that a higher precipitation is needed to support their survival. This is also the reason why the forests in the Heihe River Basin are mainly distributed upstream. Regarding the relationship between green and blue water flow and service functions of the typical ecosystems, wheat yield was significantly correlated with green water flow, and corn yield was significantly correlated with blue water flow. This showed that corn production is more dependent on blue water flow; however, wheat production will produce more green water flow. There was a significant positive correlation between green water and wheat yield. According to Table 2, this indicates that wheat production will increase as green water flow increases, and corn has the same trend with blue water flow. This showed that wheat yield is not significantly related to blue water and corn yield is not significantly related to green water (Table 1). On the one hand, this is related to the physiological and ecological characteristics of corn and wheat itself. Meanwhile, the model simulation results of this research have been added to the irrigation scenario, and corn growth is more dependent on irrigation than wheat. The living wood growing stock was significantly correlated with the green water flow, which showed that the forest consumed more green water flow than blue water flow. Beef and mutton production were significantly associated with blue water flow; however, mutton production was more strongly correlated with green water flow. Thus, mutton production will consume more green water flow than beef. This may be related to the culture structure of cattle and sheep in the Heihe River Basin; however, the model simulation results and statistics do not fully reflect the relationship between them [49]. This is a scientific question of the resource carrying capacity of the grassland in the basin, and we can examine this aspect in the future. In the future, it is necessary to further research the interaction mechanism between human activities and ecosystem service functions to determine the relationship between human activities and ecosystems.

\section{Conclusions}

In this study, we analysed the spatial and temporal distribution of green and blue water flow in typical ecosystems by applying the SWAT model. After the simulation of the water resources, a detailed investigation of the relationship between green and blue water flow and ecosystem service functions in the Heihe River Basin were conducted. The major findings are as follows:

1. The green and blue water flow per unit area in the forest ecosystem was greater than that in the farmland ecosystem; that in the cropland ecosystem was larger than that in the grassland ecosystem. However, the green and blue water flow in the grassland ecosystem was greater than that in the cropland ecosystem, and that in the cropland was larger than that in the forest ecosystem from 1971 to 2010 in the Heihe River Basin.

2. The corn yield per hectare of cropland was highest in the Heihe River Basin, followed by wheat, and the lowest yield was the oil yield from 2000 to 2010. The mutton yield in the grassland ecosystem was greater than the beef yield from 2000 to 2010, which shows that the beef production would consume more water flow. There was an obvious positive correlation between green or 
blue water flow with wheat and corn yield. The beef and mutton had a significant correlation with the blue water flow, whereas mutton had a stronger correlation with the green water flow. Overall, green water flow contributes more to ecosystem services in typical ecosystem of the arid and semi-arid regions.

Our results provide insights into the green and blue water flow distribution in typical ecosystems and service functions throughout the Heihe River Basin. These results provide a more comprehensive understanding of the spatial and temporal distributions in ecosystems and service functions of water resources in the Heihe River Basin. This could help policymakers, administrators, and researchers to manage these resources in the context of global and regional ecosystems. This information will also provide guidance for future studies of other inland river basins in China.

Author Contributions: conceptualization, C.Z.; methodology, C.Z.; software, C.Z.; validation, C.Z. and G.M.; formal analysis, G.M.; investigation, C.Z. and G.M.; resources, C.Z.; data curation, C.Z. and G.M.; writing-original draft preparation, C.Z.; writing-review and editing, C.Z. and G.M.; visualization, C.Z. and G.M.; supervision, C.Z. and G.M.; project administration, C.Z.

Funding: This research was funded by the National Natural Science Foundation of China (41625001; 51711520317; 31660233), the Strategic Priority Research Program of the Chinese Academy of Sciences, Grant No. XDA20060402, the Natural Science Foundation of Inner Mongolia Autonomous Region of China (2015BS0401), the Projects of International Cooperation and Exchanges of the NSFC (41161140353).

Acknowledgments: We thank the Inner Mongolia Agricultural University for its support and help to this research. We also thank native English-speaking editors at American Journal Experts for language polish. We also thank my other colleagues' valuable comments and suggestions that have helped improve the manuscript.

Conflicts of Interest: The authors declare no conflict of interest.

\section{References}

1. Vörösmarty, C.J.; Green, P.; Salisbury, J. Global water resources: Vulnerability from climate change and population growth. Science 2000, 289, 284-288. [CrossRef] [PubMed]

2. Oki, T.; Kanae, S. Global hydrological cycles and world water resources. Science 2006, 313, $1068-1072$. [CrossRef] [PubMed]

3. Liu, J.; Yang, H.; Gosling, S.N. Water scarcity assessments in the past, present, and future. Earth's Future 2017, 5, 545-559. [CrossRef] [PubMed]

4. Falkenmark, M. Land-Water Linkages: A Synopsis: Land and Water Integration and River Basin Management; Land and Water Bulletin No. 1; FAO: Rome, Italy, 1995; pp. 15-17.

5. Liu, J.; Yang, H. Spatially explicit assessment of global consumptive water uses in cropland: Green and blue water. J. Hydrol. 2010, 384, 187-197. [CrossRef]

6. Cheng, G.; Zhao, W. Green water and its research progresses. Adv. Earth Sci. 2006, 21, 221-227.

7. Liu, C.M.; Li, Y.H.; Liu, X.M. Impact of vegetation change on water transformation in the middle Yellow River. Yellow River 2016, 38, 7-12.

8. Falkenmark, M.; Rockström, J. The new blue and green water paradigm: Breaking new ground for water resources planning and management. J. Water Resour. Plan. Manag. 2006, 132, 129-132. [CrossRef]

9. Zang, C.F.; Liu, J.G.; Vander, V.M.; Kraxner, F. Assessment of spatial and temporal patterns of green and blue water flow under natural conditions in inland river basins in Northwest China. Hydrol. Earth Syst. Sci. 2012, 16, 2859-2870. [CrossRef]

10. Lathuillière, M.J.; Coe, M.T.; Johnson, M.S. A review of green- and blue-water resources and their trade-offs for future agricultural production in the Amazon Basin: What could irrigated agriculture mean for Amazonia. Hydrol. Earth Syst. Sci. 2016, 20, 2179. [CrossRef]

11. Gerten, D.; Hoff, H.; Bondeau, A. Contemporary green water flows: Simulations with a dynamic global vegetation and water balance model. Phys. Chem. Earth 2005, 30, 334-338. [CrossRef]

12. Jewitt, G.P.W.; Garratt, J.A.; Calder, I.R. Water resources planning and modeling tools for the assessment of land use change in the Luvuvhu Catchment, South Africa. Phys. Chem. Earth 2004, 15, 1233-1241. [CrossRef]

13. Schuol, J.; Abbaspour, K.C.; Yang, H. Modeling blue and green water availability in Africa. Water Resour. Res. 2008, 44, 212-221. [CrossRef] 
14. Zang, C.F.; Liu, J.G.; Gerten, D.; Jiang, L. Influence of human activities and climate variability on green and blue water provision in the Heihe River Basin, NW China. J. Water Clim. Chang. 2015, 6, 800-815. [CrossRef]

15. Rodrigues, D.B.; Gupta, H.V.; Mendiondo, E.M. A blue/green water-based accounting framework for assessment of water security. Water Resour. Res. 2015, 50, 7187-7205. [CrossRef]

16. Zhao, A.; Zhu, X.; Liu, X. Impacts of land use change and climate variability on green and blue water resources in the Weihe River Basin of northwest China. Catena 2016, 137, 318-327. [CrossRef]

17. Majid, E.S.; Jamshid, M.; Raghavan, S. Groundwater modeling under variable operating conditions using SWAT, MODFLOW and MT3DMS: A catchment scale approach to water resources management. Water Resour. Manag. 2018, 32, 1631-1649.

18. Costanza, R.; Arge, R.; Groot, R.; Farber, S. The value of the world's ecosystem services and natural capital. Nature 1997, 387, 253-260. [CrossRef]

19. Daily, G. Nature's Services: Societal Dependence on Natural Ecosystems; Island Press: Washington, DC, USA, 1997.

20. Costanza, R.; Groot, R.D.; Braat, L. Twenty years of ecosystem services: How far have we come and how far do we still need to go. Ecosyst. Serv. 2017, 28, 1-16. [CrossRef]

21. Potschin, M.B.; Hanesyoung, R.H. Ecosystem services. Prog. Phys. Geogr. 2011, 35, 575-594. [CrossRef]

22. Zheng, H.; Li, Y.F.; Zhao, Q.Y.; Luo, Y.C. Progress and perspectives of ecosystem services management. Acta Ecol. Sin. 2013, 33, 0702-0710. [CrossRef]

23. Xu, W.; Xiao, Y.; Zhang, J. Strengthening protected areas for biodiversity and ecosystem services in China. Proc. Natl. Acad. Sci. USA 2017, 114, 1601. [CrossRef] [PubMed]

24. Cheng, G.; Xiao, H.; Xv, Z.; Li, J. Water issue and its countermeasure in the inland river basins of northwest China: A case study in Heihe River Basin. J. Glaciol. Geocryol. 2006, 28, 406-413.

25. García-Nieto, A.P.; García-Llorente, M.; Iniesta-Arandia, I. Mapping forest ecosystem services: From providing units to beneficiarie. Ecosyst. Serv. 2018, 4, 126-138. [CrossRef]

26. Wang, Z.; Lechner, A.M.; Baumgartl, T. Ecosystem services mpping uncertainty assessment: A case study in the Fitzroy Basin Mining Region. Water 2018, 10, 88. [CrossRef]

27. Polasky, S.; Caldarone, G.; Duarte, T.K.; Goldstein, J.; Hannahs, N.; Ricketts, T.; Tallis, H. Putting Ecosystem Service Models to Work: Conservation, Management, and Trade-Offs; Oxford University Press: New York, NY, USA, 2011.

28. Zeng, J.; Li, Y.H.; Jin, Y.Z. Applicable prospect and method of in in-VEST model in water supply of ecogical system of Shiyang River Basin. J. Water Resour. Water Eng. 2015, 26, 83-87.

29. Arnold, J.G.; Fohrer, N. SWAT 2000: Current capabilities and research opportunities in applied watershed modelling. Hydrol. Process. 2005, 3, 563-572. [CrossRef]

30. Heihe Data Research Group Home Page. Available online: http://www.westgis.ac.cn/ (accessed on 18 July 2018). (In Chinese)

31. Institute of Resources and Environment Data Cloud Platform, Chinese Academy of Sciences (CAS) Home Page. Available online: http:/ / www.resdc.cn/ (accessed on 12 September 2018). (In Chinese)

32. Harmonized World Soil Database Home Page. Available online: http://www.iiasa.ac.at (accessed on 7 August 2018).

33. Ritchie, J.T. Model for predicting evaporation from a row crop with incomplete cover. Water Resour. Res. 1972, 8, 1204-1213. [CrossRef]

34. Neitsch, S.L.; Arnold, J.G.; Kiniry, R. Soil and Water Assessment Tool Input/Output File Documentation Version 2005; Grassland, Soil and Water Research Laboratory Angriculture Research Services \& Black Land Research Center Texas Agricultual Experiment Station: Temple, TX, USA, 2004; pp. 50-80.

35. Abbaspour, K.C.; Yang, J.; Maximov, I.R. Modelling hydrology and water quality in the pre-Alpine/Alpine Thur watershed using SWAT. J. Hydrol. 2007, 333, 413-430. [CrossRef]

36. China Economic and Social Development Statistics Database Home Page. Available online: http://tongji. cnki.net/kns55/Dig/dig.aspx (accessed on 10 June 2018). (In Chinese)

37. Cheng, R.T.; Feng, J.; Ma, Y.Q.; Feng, Z.K. Linear compatible model layer biomass of pinus tabulaeform is platation in Xiaolong Moutains. Chin. J. Ecol. 2008, 27, 317-322.

38. Northwest Forestry Investigation and Planning Institute of the State Forestry Bureau Home Page. Available online: http:/ / xby.forestry.gov.cn/ (accessed on 11 July 2018). (In Chinese) 
39. Ezekiel, M. Methods of Correlation Analysis; Revista Mexicana De Sociología; John Wiley \& Sons Inc.: Hoboken, NJ, USA, 1942.

40. Pyper, P. Comparison of methods to account for autocorrelation in correlation analysis of fish data. Can. J. Fish. Aquat. Sci. 1998, 55, 2127-2140. [CrossRef]

41. Zhao, S.X.; Zhang, Y.S.; Zhao, X.Q. Research on evapotranspiration and its impact factors on grassland in the northern slopes of Qilianshan Mountains. Nat. Sci. Ed. 2008, 36, 109-115.

42. Zhang, W.; Zha, X.; Li, J. Spatiotemporal change of blue water and green water resources in the headwater of Yellow River Basin, China. Water Resour. Manag. 2014, 28, 4715-4732. [CrossRef]

43. Ringgaard, R.; Herbst, M.; Friborg, T. Partitioning forest evapotranspiration: Interception evaporation and the impact of canopy structure, local and regional advection. J. Hydrol. 2014, 517, 677-690. [CrossRef]

44. Sun, X.; Wang, G. A review of forest hydrology study and its spatial pattern for dark coniferous forest in Gongga Mountain, southwest China. Mt. Res. 2017,5. Available online: http:/ / en.cnki.com.cn/Article_en/ CJFDTOTAL-SDYA201705009.htm (accessed on 17 October 2018).

45. Adane, Z.A.; Nasta, P.; Zlotnik, V. Impact of grassland conversion to forest on groundwater recharge in the Nebraska Sand Hills. J. Hydrol. Reg. Stud. 2018, 15, 171-183. [CrossRef]

46. Lana-Renault, N.; López-Vicente, M.; Nadal-Romero, E. Catchment based hydrology under post farmland abandonment scenarios. Cuadernos De Investigacion Geografica 2018. [CrossRef]

47. Boerema, A.; Meire, P. Management for estuarine ecosystem services: A review. Ecol. Eng. 2017, 98, $172-182$. [CrossRef]

48. Fu, Y.; Zhang, J.; Zhang, C. Payments for ecosystem services for watershed water resource allocations. J. Hydrol. 2018, 556, 689-700. [CrossRef]

49. Garciaprats, A.; Gonzálezsanchis, M.; Del, A.C. Hydrology-oriented forest management trade-offs. A modeling framework coupling field data, simulation results and Bayesian Networks. Sci. Total Environ. 2018, 639, 725-741. [CrossRef]

(C) 2019 by the authors. Licensee MDPI, Basel, Switzerland. This article is an open access article distributed under the terms and conditions of the Creative Commons Attribution (CC BY) license (http:/ / creativecommons.org/licenses/by/4.0/). 